DOI https://doi.org/10.18551/rjoas.2018-11.06

\title{
FACTORS AFFECTING THE INTEGRITY OF FINANCIAL STATEMENTS IN MANUFACTURING COMPANIES LISTED IN INDONESIA STOCK EXCHANGE
}

\author{
Putri Cintamy Prananti \\ Department of Accounting, University of Airlangga, Surabaya, Indonesia \\ E-mail: cintamypp@gmail.com
}

\begin{abstract}
Good financial statements are the financial statements which have integrity of the information contained. Integrity of the financial statements is the extent to which the financial statements present financial information fairly, honestly and unbiased. Integrity of the financial statements is very important for the users, especially external parties that have lower information to make decisions. The phenomenon of financial scandals that still occur in Indonesia indicates a failure to form the integrity of financial statements to meet the information needs of users of financial statements. This research aims obtain empirical evidence about the influence of internal and external companies for integrity of the financial statements of companies listed in Indonesia Stock Exchange (IDX) in 2012-2016. Factors of companies, among others, institutional ownership by financial institutions, independent commissioners, audit committee, audit quality and audit tenure. This study is a quantitative study aimed to examine the effect of independent variables independent variable. The statistical method used was multiple linear regression analysis using SPSS 20 . The method use purposive sampling and there are 39 samples that fulfill sample criteria. The results of this research indicate that institutional ownership by financial institutions and independent commissioner does not affect to integrity of the financial statements, while the audit committee a positive effect to integrity of the financial statements. Audit quality and audit tenure obtain results that audit quality does not affect to integrity of the financial statements and audit tenure positive effect to integrity of the financial statements.
\end{abstract}

\section{KEY WORDS}

Integrity, financial statements, institutional ownership, financial institutions, independent commissioners, audit committee, audit quality, audit tenure.

The financial statements also show the results of management's accountability for the use of resources entrusted to them. The report provides information that can be used by internal parties such as commissioners, directors, managers and employees as well as external parties such as investors, creditors and suppliers to make decisions. Quality financial statements must be able to provide relevant and useful information in economic decision making and investment decisions for its users. Accounting information must fulfill three qualitative characteristics of accounting information, namely relevance, objectivity, and reliability. According to Hardiningsih (2010) information is said to be relevance if it can influence the decisions of users of financial statements by strengthening or changing the expectations of users of financial statements. Information is said to be reliable if it can be trusted and causes users of financial statements to depend on that information. While said objective if the information is free from the influence of other things that can affect the independence of information. Financial report integrity can be achieved if the financial statements are able to provide information that has these characteristics.

Financial report integrity is the extent to which financial statements present information that is true, honest, accurate and free from actions or activities undertaken and intentional by the management of the company in manipulating the accounting numbers contained in the report to mislead the users of financial statements in assessing their company (Mayangsari\&Wilopo, 2002). External users are in the condition of the greatest uncertainty that requires financial statements as to determine the company's performance (Okpala, 2012). Financial report integrity is very important for users, especially external parties who 
have lower information than internal parties, namely management to make decisions. However, in Indonesia there are currently many legal cases involving accounting manipulation. The phenomenon of financial scandal that still occurs shows a form of failure of the integrity of financial statements to meet the information needs of users of financial statements. Based on the results of the examination of Bapepam-LK, found evidence that the presentation of financial statements of PT. Indofarma Tbk. too high in the 2001 financial year. In addition, during 2012 until 2016, Bapepam-LK still handled approximately 70 cases of alleged violations of laws and regulations in the capital market sector.

The company's internal factors that will be used in this study consist of institutional ownership by financial institutions, independent commissioners, and audit committees which are part of corporate governance. Elements of corporate governance are contained in financial statements which are a series of processes, habits, policies, rules and institutions that influence the direction, management, and control of a company or corporation. The external factors of the company are seen from external auditors that are proxied by audit quality and audit tenure. The quality of Public Accountant Office in this study refers to Public Accountant Office name or audit brand name which is reflected in the collaboration with the Foreign Public Accountant Office. In addition to audit quality measured by looking at the Public Accountant Office included in the big four or not, audit tenure can affect the assessment of the integrity of financial statements based on the audit engagement period between the auditor and the client and the audit experience that is owned.

There are many differences to the results of research conducted by previous researchers making research on financial integrity is still important to be re-examined. Departing from the contradiction of the results of research conducted by Arvida (2013), Putra \& Muid (2012), Gayatri \& Suputra (2013), and Nicolin \& Sabeni (2013) who found that institutional ownership with a percentage of institutional shares was divided by the number of outstanding shares affect the integrity of financial statements. However, research by Efrianti (2012) and Wulandari \& Budiartha (2014) states that institutional ownership with proxy for the percentage of institutional shares divided by the number of outstanding shares has an influence on the integrity of financial statements. Researchers suspect that differences in the results of research on institutional ownership due to the proxy previously used share ownership of all institutions both financial and non-financial institutions. So the researchers want to propose an institutional ownership proxy by only calculating the percentage of share ownership by financial institutions. This proxy submission is due to institutional ownership by financial institutions having better financial knowledge than other institutions. Financial institutions usually hand over responsibility to the investment division (investment manager) who has the knowledge and information to analyze and manage the company's investment.

\section{THEORY AND HYPOTHESES DEVELOPMENT}

Agency Theory. Eisenhardt (1989) says that agency theory is based on several assumptions which are divided into three, namely assumptions about human nature, organizational assumptions, and information assumptions. The assumption of human nature emphasizes that humans have self-interest, have limited rationality and do not like risk aversion. Agency relations are described as a contract under one or more principals that involves agents to carry out several services for them by delegating decision-making authority to agents (Jensen \& Meckling, 1976). Agency problems arise because of the principal between the principal and the agent. Each party, both principal and agent, are like to maximize personal interests. The principal has the desire to increase the value of investment in the company and get the maximum profit for his investment. In addition, the agent has a personal interest that is adequate compensation for the performance and obligations that he has done.

Integrity of Financial Statements. Financial statements with integrity according to Mayangsari \& Wilopo (2002), can be assessed by using the principle of conservatism and the use of earnings management because the information in the financial statements will be more reliable if the financial statements are conservative and the financial statements are not 
overstated so that no party is harmed due to information in the financial statements. Conservatism is a precautionary principle in recognizing assets and profits because of economic and business activities that are surrounded by uncertainty (Wawo, 2013).

Effect of Institutional Ownership on the Integrity of Financial Statements. Financial institutions usually hand over responsibilities to certain divisions that have the knowledge and information in the financial sector to analyze and manage company investments. Institutional investors by financial institutions are assumed to be able to analyze properly so that they can avoid management manipulation in the issuance of financial statements.

$\mathrm{H}_{1}$ : Institutional ownership by financial institutions has a positive effect on the integrity of financial statements.

Effect of the Independent Commissioner on the Integrity of Financial Statements. The existence of an independent commissioner in a company can affect the integrity of financial statements produced by management. If the company has an independent commissioner, the financial statements presented by management tend to be more integrity, because there are bodies that supervise and protect rights outside the company (Fitrawansyah \& Syahnifah, 2018).

$\mathrm{H}_{2}$ : Independent commissioners have a positive effect on the integrity of financial statements.

Effect of the Audit Committee on the Integrity of Financial Statements. The audit committee in the company can be one of the efforts in reducing fraud in the presentation of financial statements so that the audit committee is expected to improve supervision of management actions that allow manipulation of financial statements that affect the integrity of financial statements (Priharta, 2017).

$\mathrm{H}_{3}$ : The audit committee has a positive effect on the integrity of the financial statements.

Effect of Audit Quality on the Integrity of Financial Statements. Public Accountant Office big four has a good reputation in the eyes of users of financial statements. So that to maintain that Public Accountant Office big four will try not to betray public trust by assessing the fairness of the financial statements in truth.

$\mathrm{H}_{4}$ : Audit quality has a positive effect on the integrity of financial statements.

Effect of Audit Tenure on Integrity of Financial Statements. Knapp (1991) shows that the length of the relationship between auditee and auditor can disrupt the independence and accuracy of the auditor to carry out auditing duties. In the auditor-client relationship there is a tendency that over time, the auditor gradually adjusts to various management desires and then does not act fully independently.

$\mathrm{H}_{5}$ : Audit Tenure has a negative effect on the integrity of financial statements.

The research framework that underlies this research can be described as follows:

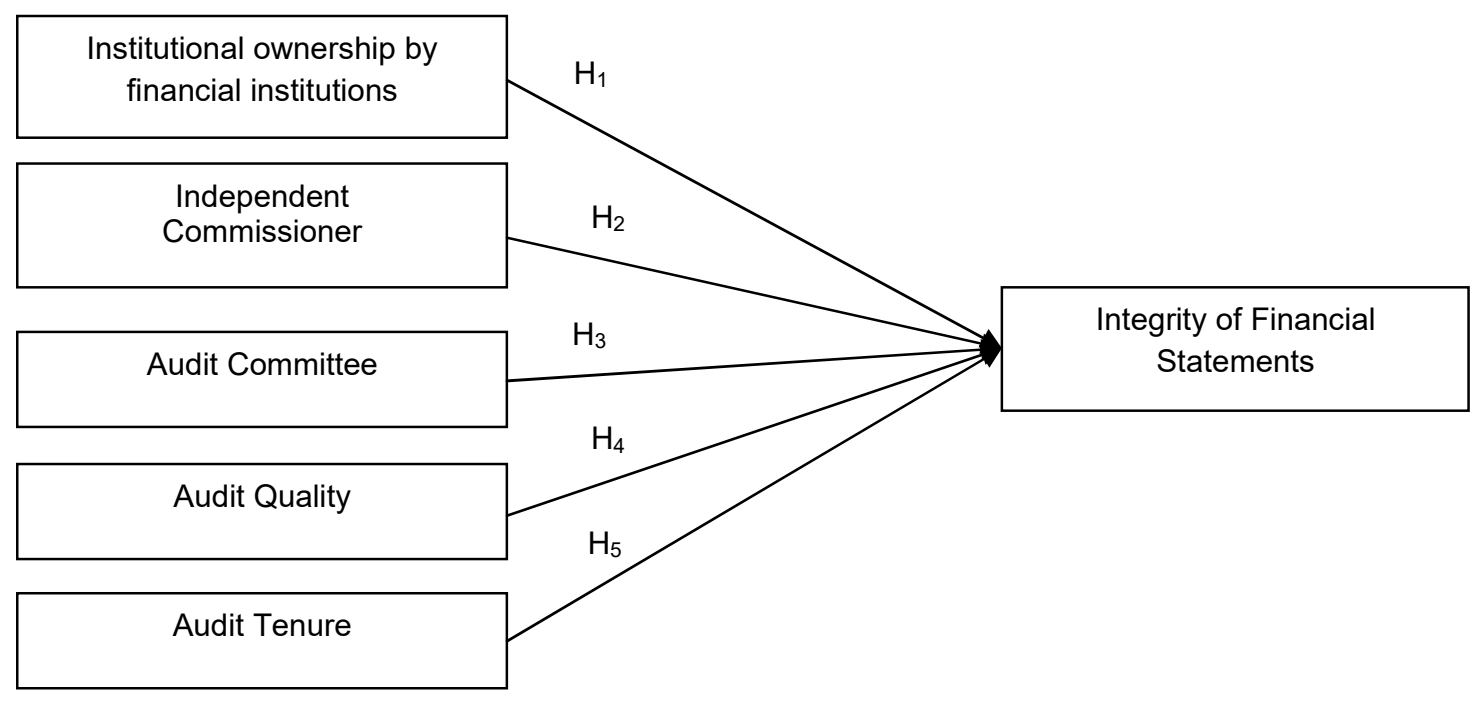

Figure 1 - Conceptual framework 


\section{METHODS OF RESEARCH}

This study uses a quantitative approach, namely research that focuses on testing hypotheses that explain the relationship between variables. Quantitative research aims to examine the influence of internal factors (institutional ownership, independent commissioners, and audit committee) and external factors (audit quality and audit tenure).

The population used in this study is manufacturing companies listed on the Indonesia Stock Exchange (IDX) for 5 consecutive years in 2012-2016. Sampling in this study uses purposive sampling method.

Mayangsari \& Wilopo (2002) defines the integrity of financial statements as the extent to which the financial statements presented can show true and honest information. In this study the integrity of financial statements is measured using conservatism. Conservatism is proxied by using accrual (earning / accrual measures), namely the difference between net income and cash flow. Conservatism with accrual measures is calculated by the formula below as used by Givoly and Hayn (2000):

\section{CONACCit $=$ Nlit - CFOit}

Where: CONACCit $=$ the level of conservatism of the company $\mathrm{i}$ in year $\mathrm{t}$; $\mathrm{Nlit}=\mathrm{Net}$ income before extraordinary items are added with depreciation and amortization; CFOit = Cash flow from activities.

Institutional ownership is the percentage of voting rights held by an institution (Beiner et al., 2003). Institutional ownership by financial institutions can oversee management performance because financial institutions have better financial knowledge than other institutions. In addition, financial institutions are considered as sophisticated investors so that they are not easily deceived by manager's actions.

$$
\text { INSTK }=\frac{\text { the proportion of shares held by financial institutions }}{\text { total number of shares outstanding }}
$$

Independent commissioners are non-affiliated commissioners with other controlling shareholders, directors and boards of commissioners, and the company itself both in the form of business and family relationships.

$$
\text { INSTK }=\frac{\text { member of the independent commissioner }}{\text { total number of board members }}
$$

According to Rachmawati and Hanung (2007) the audit committee has a very important and strategic role in terms of maintaining the credibility of the financial report preparation process as well as maintaining the creation of an adequate corporate supervision system and the implementation of good corporate governance. The audit committee is assessed by the number of audit committee scores based on two criteria then divided by the maximum number of scores from these criteria. The criteria used by the researcher for audit committee variables are (1) formal audit committee education with educational background in business or economics, and (2) audit committee experience.

The size of Public Accountant Office in this study is the size of the Public Accountant Office which is divided into two groups, namely Public Accountant Office affiliated with the big four and Public Accountant Office that are not affiliated with the big four (Choi et al., 2010) and measured using a dummy variable where number 1 is given if the auditor who audits the company is the auditor of the big four Public Accountant Office and 0 if it turns out the company is audited by a non big four Public Accountant Office.

Audit tenure is a period of audit engagement from a Public Accountant Office in providing audit services to its clients. Calculation of the number of years of engagement carried out by counting backwards, starting from 2012, then traced to where the client moves to another auditor (Boone et al., 2008) 
Data analysis method used in this study using multiple regression analysis with the help of SPSS 20.0 statistical program. This classic assumption test is done so that in this study the results of data analysis that meet the testing requirements are obtained, then the research is carried out by testing the classical assumptions for statistical testing. The multiple regression model used in this study is stated in the following equation:

$$
Y=a+b 1 X 1+b 2 X 2+b 3 X 3+b 4 X 4+b 5 X 5+e
$$

Where: $Y=$ Financial Report Integrity (KONS); $a=$ Constants; b1a-b5= Regression Coefficient; $\mathrm{X} 1$ = Institutional Ownership by financial institutions (INSTK); $\mathrm{X} 2$ = Independent Commissioner (IND); X3 = Audit Committee (KOM); X4 = Audit Quality (KA); X5 = Audit Tenure (TENURE); e = Estimated error.

\section{RESULTS AND DISCUSSION}

Descriptive Statistics Test Results. Table 4.1 shows the description of the independent variable and the dependent variable of the study statistically by the number of observations (N) is 39. Institutional ownership by financial institutions (INSTK) has an average (mean) of 0.1515 with a standard deviation of 0.25680 . The minimum value of institutional ownership by a financial institution is 0.00 or does not have share ownership $(0 \%)$. The maximum value of INSTK is 0.87 or $87 \%$ at PT. Indospring Tbk.

Table 1 - Descriptive Statistics

\begin{tabular}{llllll} 
& N & Minimum & Maximum & Mean & Std. Deviation \\
\hline INSTK & 39 & .00 & .87 & .1515 & .25680 \\
IND & 39 & .00 & .67 & .4034 & .12857 \\
KOM & 39 & .33 & 1.00 & .6156 & .16771 \\
KA & 39 & .00 & 1.00 & .3077 & .46757 \\
TENURE & 39 & 1.00 & 6.00 & 3.0256 & 1.49538 \\
CONACC & 39 & -30.05 & -.62 & -5.2454 & 6.53361 \\
Valid N (listwise) & 39 & & & & \\
\hline
\end{tabular}

Source: Data Processed (2017).

The average value of independent commissioners (IND) in the table above is 0.4034 and the standard deviation is 0.12857 . PT. Kertas Basuki Rachmat Indonesia Tbk has a minimum value of 0.00 where in that year the company did not have an independent commissioner. The maximum value of IND is 0.67 at PT. Jembo Cable Company Tbk with 3 commissioners and 2 independent commissioners.

The audit committee (KOM) has a minimum value of 0.33 and a maximum value of 1.00 or $100 \%$. The maximum value of KOM is found in PT. Indomobil Sukses Internasional Tbk where all audit committees have educational background and experience in the economic field. The results of descriptive statistics show the average value of the audit committee is 0.6156 with a standard deviation of 0.16771 .

Audit quality (KA) shows an average value of 0.3077 and a standard deviation of 0.46757 . The lowest value of audit quality is 0.00 and the highest is 1.00 at PT. Bentoel Internasional Investama Tbk, PT. Unitex Tbk, and PT. Delta Djakarta Tbk.

The average audit tenure (TENURE) value from 2008-2012 was 3.0256 with a standard deviation of 0.46757 . The minimum audit tenure value is 1.00 and the maximum value is 6.00 where the maximum value is PT. Pyridam Farma Tbk.

Financial report integrity has the lowest value of -30.05 and the maximum value is 0.62 . The lowest value of conservatism measurement was obtained by PT. Alumindo Light Metal Industry Tbk. PT. Indomobil Sukses Internasional Tbk obtained the maximum value with the most conservative financial statements of all research samples.

Determination Coefficient Test Results. Based on the output of the summary model shown in table 2, the adjusted R-Square value is 0.455 , this means that $45.5 \%$ of the integrity of financial statements can be explained by variations of the five independent 
variables. While the remaining $55.5 \%$ is explained by other reasons outside the research model.

Table 2 - Determination Coefficient

Model Summary

\begin{tabular}{llllll} 
Model & $\mathrm{R}$ & $\mathrm{R}$ Square & Adjusted R Square & Std. Error of the Estimate & Durbin-Watson \\
\hline 1 & $.727^{\mathrm{a}}$ & .528 & .455 & 5.12544 & 1.848 \\
\hline
\end{tabular}

a. Predictors: (Constant), TENURE, KA, IND, KOM, INSTK

b. Dependent Variable: CONACC

Source: Data Processed (2017).

Results of the Regression Model. T test is conducted to determine whether the independent variables in the regression model affect individually the dependent variable. The hypothesis is accepted if the significant value is less than 0.05 and is rejected if the significance value is more than 0.05 .

Table 3 - Statistical T Test Results

\begin{tabular}{|c|c|c|c|c|c|}
\hline \multirow[t]{2}{*}{ Coefficients $^{a}$} & \multicolumn{2}{|c|}{ Unstandardized Coefficients } & Standardized Coefficients & \multirow[t]{2}{*}{$-\mathrm{T}$} & \multirow[t]{2}{*}{ Sig. } \\
\hline & $\mathrm{B}$ & Std. Error & Beta & & \\
\hline 1 (Constant) & -32.907 & 5.838 & & -5.637 & .000 \\
\hline INSTK & -5.232 & 3.337 & -.213 & -1.568 & .127 \\
\hline IND & 11.980 & 6.569 & .227 & 1.824 & .078 \\
\hline KOM & 17.658 & 4.715 & .503 & 3.745 & .001 \\
\hline $\mathrm{KA}$ & 1.297 & 1.627 & .106 & .797 & .431 \\
\hline TENURE & 1.546 & .557 & .356 & 2.776 & .009 \\
\hline
\end{tabular}

a. Dependent Variable: CONACC.

Testing the first hypothesis in table 3 obtained a significance probability of 0.127 , this indicates that the probability is more than 0.05 . Therefore it can be concluded that institutional ownership by financial institutions does not affect the integrity of financial statements, so the first hypothesis is rejected. Independent commissioners have a significance probability of 0.078 , thus showing a significance of more than 0.05 . This means that the independent commissioner does not affect the integrity of the financial statements and hypothesis 2 is rejected. The audit committee has a positive influence on the integrity of financial statements. This result is indicated by the probability of audit committee significance of 0.001 and $t$ is 3.745 , so hypothesis 3 is accepted.

Probability of significance of audit quality is 0.431 . This shows that a significant probability is greater than 0.05 , so that audit quality does not affect the integrity of the financial statements hypothesis 4 is rejected.

The results shown in table 3 show that audit tenure has a significance level of less than 0.05 , that is 0.009 , so that it can be concluded that hypothesis 5 is rejected, audit tenure has a positive effect on the integrity of financial statements.

Effect of Institutional Ownership on the Integrity of Financial Statements. The results of regression analysis indicate that institutional ownership by financial institutions does not affect the integrity of financial statements. The high or low percentage of the company's shareholdings owned by the financial institutions do not have an influence on the integrity of the financial statements. These results are contrary to the research hypothesis proposed by the researchers.

Effect of the Independent Commissioner on the Integrity of Financial Statements. The researcher obtained the results that each company held a meeting with different frequencies even though the percentage of independent commissioners was not different. It showed that independent commissioners still did not perform the function of good corporate governance to the maximum extent possible. In addition, researchers assume that independent 
commissioners do not have an influence on the integrity of financial statements due to the role of independent commissioners, namely to balance decision making and protection of minority shareholders so that the supervision carried out is not fully directly related to accounting numbers.

Effect of the Audit Committee on the Integrity of Financial Statements. The test results have proven that the audit committee has a positive effect on the integrity of the financial statements with a significance value that is much smaller than 0.05 . The entire sample company has complied with Bapepam regulations which require each company to have a minimum of three audit committees. This shows that the existence of an audit committee that has a formal education background in economics and business as well as experience in various activities, can make the integrity of financial statements higher or conservative.

Effect of Audit Quality on the Integrity of Financial Statements. The results show that audit quality measured by a dummy for big four and non-big four Public Accountant Office does not affect the integrity of financial statements. This explains that in companies that use the services of big four or non-big four Public Accountant Office do not have an influence on the high and low application of accounting conservatism in the financial statements. This shows that even though the Public Accountant Office in the research sample is not a big four Public Accountant Office, the Public Accountant Office is affiliated with Foreign Public Accountant Office so the quality, the credibility and reputation of the Public Accountant Office are also at the international level (world class).

Effect of Audit Tenure on Integrity of Financial Statements. The results of this study prove that the length of relationship between auditee and Public Accountant Office can increase the independence and accuracy of Public Accountant Office to carry out auditing tasks so that the longer the engagement period between Public Accountant Office and the client company, the higher the conservative level of the report. The existence of a positive influence from audit tenure that reflects the independence of Public Accountant Office on the integrity of financial statements shows that the company does not view the longer period of Public Accountant Office engagement as the basis for presenting financial statements to be not conservative. This is due to the consideration that changes from conservative accounting to optimism will be avoided by companies to reduce investor suspicions or other users of financial statements.

\section{CONCLUSION AND SUGGESTIONS}

This research prove that institutional ownership by financial institutions and independent commissioner does not affect to integrity of the financial statements, while the audit committee a positive effect to integrity of the financial statements. Audit quality and audit tenure obtain results that audit quality does not affect to integrity of the financial statements and audit tenure positive effect to integrity of the financial statements. The audit committee and audit tenure have an effect on the integrity of the financial statements so that it can be taken into consideration for investors to make investment decisions by looking at the educational background and experience of the audit committee of a company and the period of the company's engagement with the relevant Public Accountant Office. The appointment of audit committees within the company is better for individuals who have educational background and experience in the field of economics or business, thus creating good corporate governance and improving the integrity of the company's financial statements.

Limitations in this research are (1) the research period used is only 5 years, so to see the negative trends in the company is still lacking; (2) the independent variable used in this study only explained $45.5 \%$ of the dependent variable while the remaining $55.5 \%$ was explained by other variables. Based on the limitations of the results of the above research, the suggestion that the researcher can give is that the researcher is expected to be able to add independent variables and increase the influence of the independent variables that are greater than this research. Then, further research is expected to increase the period of research to see the negative trends that exist in the company. 


\section{REFERENCES}

1. Ahmed, A. S., Billings, B. K., Morton, R. M., \& Stanford-Harris, M. (2002). The role of accounting conservatism in mitigating bondholder-shareholder conflicts over dividend policy and in reducing debt costs. The Accounting Review, 77(4), 867-890.

2. Al-dhamari, R., \& Ku Ismail, K. N. I. (2015). Cash holdings, political connections, and earnings quality: Some evidence from Malaysia. International Journal of Managerial Finance, 11(2), 215-231.

3. Arvida, L. (2013). Pengaruh Mekanisme Corporate Governance, Kualitas Kantor Akuntan Publik dan Audit Tenure Terhadap Integritas LaporanKeuangan (Studi Empiris pada Perusahaan Manufaktur yang terdaftar di BEI).

4. Beiner, S., Drobetz, W., Schmid, F., \& Zimmermann, H. (2004). Is board size an independent corporate governance mechanism?.Kyklos, 57(3), 327-356.

5. Belkaoui, A. Riahi (2006). Accounting Theory.

6. Brigham, E. F., \& Houston, J. F. (2006). Dasar-dasar manajemen keuangan. Jakarta: Salemba Empat.

7. Brilianti, D. P. (2013). Faktor-faktor yang Mempengaruhi Penerapan Konservatisme Akuntansi Perusahaan. Accounting Analysis Journal, 2(3).

8. Boone, Louis E. Kurtz, dan David L. (2008). Contempopary Business = Pengantar Bisnis Kontemporer. Buku 1. Jakarta: Salemba Empat.

9. Choi, J. H., Kim, C., Kim, J. B., \& Zang, Y. (2010). Audit office size, audit quality, and audit pricing. Auditing: A Journal of practice \& theory, 29(1), 73-97.

10. Efrianti, D. (2012). Pengaruh Kepemilikan Institusional, KomisarisIndependen Dan Komite Audit Terhadap Integritas Informasi Laporan Keuangan. Jurnal IImiah Ranggagading (JIR), 12(2), halaman-119.

11. Eisenhardt, K. M. (1989). Agency theory: An assessment and review. Academy of management review, 14(1), 57-74.

12. Emirzon, J. (2007). Prinsip-prinsip good corporate governance: paradigm baru dalam praktik bisnis Indonesia. Genta Press.

13. Fama, E. F., \& Jensen, M. C. (1983). Separation of ownership and control. The journal of law and Economics, 26(2), 301-325.

14. Fitrawansyah, F., \& Syahnifah, M. (2018). Pengaruh Independensi Auditor Terhadap Integritas Laporan Keuangan (Studi Empiris pada Perusahaan Manufaktur yang Terdaftar di Bursa Efek Indonesia Periode 2013-2015)". Akuntabilitas, 11(2), 245-256.

15. Francis, J., LaFond, R., Olsson, P., \&Schipper, K. (2005). The market pricing of accruals quality. Journal of accounting and economics, 39(2), 295-327.

16. Gayatri, I. A. S., \& Suputra, I. D. G. D. (2013). Pengaruh Corporate Governance, Ukuran Perusahaan dan Leverage Terhadap Integritas Laporan Keuangan. E-Jurnal Akuntansi, 5(2), 345-360.

17. Givoly, D., \& Hayn, C. (2000). The changing time-series properties of earnings, cash flows and accruals: Has financial reporting become more conservative?.Journal of accounting and economics, 29(3), 287-320.

18. Guna, W. I., \& Herawaty, A. (2010). Pengaruh Mekanisme Good Corporate Governance, Independensi Auditor, Kualitas Audit dan Faktor Lainnya Terhadap Manajemen Laba. Jurnal bisnis dan akuntansi, 12(1), 53-68

19. Hair, J. F., Black, W. C., Babin, B. J., Anderson, R. E., \& Tatham, R. L. (1998).Multivariate data analysis (Vol. 5, No. 3, pp. 207-219). Upper Saddle River, NJ: Prentice hall.

20. Hardiningsih, P. (2010). Pengaruh independensi, corporate governance, dan kualitas audit terhadap integritas laporan keuangan. Jurnal Ilmiah Kajian Akuntansi, 2(1).

21. Irfan, A. (2002). Pelaporan Keuangan dan Asimetri Informasi dalam Hubungan Agensi. Lintasan Ekonomi, 19(2), 9-10.

22. Jensen, M. C., \& Meckling, W. H. (1976). Theory of the firm: Managerial behavior, agency costs and ownership structure. Journal of financial economics, 3(4), 305-360.' 
23. Knapp, M. C. (1991). Factors that audit committee members use as surrogates for audit quality. Auditing-A Journal Of Practice \& Theory, 10(1), 35-52.

24. Kootanaee, A. J., Seyyedi, J., Nedaei, M., \& Kootanaee, M. J. (2013). Accounting conservatism and corporate governance's mechanisms: Evidence from Tehran stock exchange. International Journal of Economics, Business and Finance, 1(10), 301-319.

25. Louwers, T. J. (1998). The relation between going-concern opinions and the auditor's loss function. Journal of Accounting research, 36(1), 143-156.

26. Mayangsari, S., \& Wilopo, W. (2002). Konservatisme Akuntansi, Value Velevance dan Discretionary Accruals: Implikasi Empiris Model Feltham-Ohlson (1996). The Indonesian Journal of Accounting Research, 5(3).

27. Nicolin, O., \& Sabeni, A. (2013). Pengaruh struktur corporate governance, audit tenure, danspesialisasi industri auditor terhadap integritas laporan keuangan.Diponegoro Journal of Accounting, 2(3), 1-12.

28. Okpala, K. E. (2012). Audit committee and integrity of financial statements: a preventive mechanism for corporate failure. Australian journal of business and management research, 2(8), 32-40.

29. Priharta, A. (2017). Pengaruh Corporate Governance Terhadap Integritas Laporan Keuangan. JABE (Journal of Applied Business and Economic), 3(4), 234-250.

30. Putra, Daniel dan Dul Muid. (2012). Pengaruh Independensi, Mekanisme Corporate Governance, Kualitas Audit, Dan Manajemen Laba Terhadap Integritas Laporan Keuangan. Diponegoro Journal Of Accounting Volume 1, Nomor 2, Tahun 2012

31. Rachmawati, A., \& Triatmoko, H. (2007). Analisis faktor-faktor yang mempengaruhi kualitas laba dan nilai perusahaan. Simposium Nasional Akuntansi X, 1-26.

32. Ridwan, M., \& Gunardi, A. (2017). Peran Mekanisme Corporate Governance sebagai Pemoderasi Praktik Earning Management terhadap Nilai Perusahaan. Trikonomika, 12(1), 49-60.

33. Wawo, A. (2013). Pengaruh corporate governance dan konsentrasi kepemilikan terhadap daya informasi akuntansi. AKMEN Jurnal IImiah, 10(2).

34. Wolk, H. I., \& Tearney, M. G. (1997).Accounting theory: A conceptual and institutional approach.Thomson South-Western.

35. Wulandari, N. P., \& Budiartha, I. K. (2014).Pengaruh Struktur Kepemilikan, Komite Audit, Komisaris Independen dan Dewan Direksi Terhadap Integritas Laporan Keuangan. EJurnal Akuntansi, 7(3), 574-586. 